Article

\title{
Strength Development and Durability of Concrete Containing Recycled Roof Tile Aggregate
}

\author{
Alhagie Bakary Ceesay ${ }^{1, * \mathbb{D}}$ and Shingo Miyazawa ${ }^{2}$ \\ 1 Graduate School of Engineering, Ashikaga University, Ashikaga 326 8558, Japan \\ 2 Department of Civil Engineering, Ashikaga University, Ashikaga 326 8558, Japan \\ * Correspondence: albacee83@gmail.com; Tel.: +81-808-118-9445
}

Received: 31 May 2019; Accepted: 16 July 2019; Published: 18 July 2019

check for updates

\begin{abstract}
The use of recycled aggregate in new concrete has often been limited due to concerns over their quality and structural performance. This research aims to investigate the physical properties of recycled roof tile aggregate and its suitability for concrete production. Physical properties of recycled roof tile aggregate are compared to normal crushed stone aggregate. Effects of recycled roof tile aggregates on strength and durability of recycled roof tile concrete was compared with normal aggregate concrete using mechanical properties and durability tests. The experimental results showed that high water absorption and low strength of aggregate have a great effect on the workability and strength of the concrete containing recycled roof tile aggregate. Aggregate density, water absorption, crushing value and abrasion value of the recycled roof tile aggregate were found to be lower than crushed stone aggregate and concrete containing recycled roof tile aggregate had low strength and slow strength development. Similar durability performance of recycled roof tile aggregate concrete and normal aggregate concrete was observed except when exposed to freezing and thawing.
\end{abstract}

Keywords: recycled roof tile aggregate; recycled roof tile aggregate concrete; concrete durability; mechanical properties

\section{Introduction}

The use of concrete in different civil engineering applications has placed a high demand on constituent materials. Tremendous degradation of natural areas has been occurring over the years due to a large expansion of the construction industry and the continuous use of natural resources [1]. The advancement in the construction industry introduces several concerns regarding the availability of natural aggregate resources, as they are being rapidly depleted. High annual aggregate production has a significant impact on the environment [2]. In published papers, one of the objectives of the new waste reuse and recycling policies in the construction and industrial sectors is to use recycled aggregates as a substitute for conventional natural aggregates, with the aim of reducing both use of natural resources and environmental impact caused by dumping [3]. These waste materials can solve problems like lack of aggregates in construction sites and environmental problems [4]. This paper provides additional knowledge of material properties of recycled roof tile aggregate, strength and durability performance of concrete containing recycled roof tile as coarse aggregate. Suitability of recycled waste materials, like roof tile in concrete production, would go a long way in addressing the high dependency on natural mineral aggregate, aggregate depletion issue, and environmental problem.

In published papers, usage of demolished roof tile as an aggregate of concrete has recently been proposed. The use of waste clay tiles as a partial replacement of aggregate in concrete is one of the alternatives to the virgin aggregate [5]. It is reported that shrinkage of concrete is decreased by using recycled roof tile aggregate due to the effect of internal curing by the moisture supply of aggregate particles to the surrounding cement paste [6]. Although the strength of recycled roof tile aggregate 
particles is usually lower than the normal crushed stone aggregate, compressive strength of concrete with roof tile aggregate is often similar to or larger than the normal crushed stone aggregate $[7,8]$. Additional study on the properties of concrete containing recycled roof tile aggregate is still needed to utilize it more effectively. In this study, properties of recycled roof tile aggregate and its suitability for concrete production is investigated. Physical properties of recycled roof tile aggregate are compared to normal crushed stone. Similarly, mechanical properties and durability of concrete containing recycled roof tile aggregate are compared to normal aggregate concrete in order to evaluate the effect of recycled roof tile aggregate on strength and durability of concrete.

\section{Materials and Methods}

\subsection{Materials Used}

Ordinary Portland cement conforming to Japanese Industrial Standards (JIS) R 5210 [9] from the same source was used throughout the experiment. River sand (S) and fine recycled roof tile (RTS) were used as fine aggregate while crushed sandstone $(\mathrm{G})$ and coarse recycled roof tile (RTG) were used as coarse aggregate for the different mix proportions of concrete. In addition, air entraining agent (AE), air entraining and water reducing agent (AEWR) and superplasticizer (SP) were used as chemical admixtures in accordance with JIS A 6204 [10]. Both coarse and fine recycled roof tile aggregate samples were subjected to sieve analysis in accordance with JIS A 1102 [11] to obtain the gradation curve and fineness modulus. Tests of specific gravity, water absorption, aggregate crushing value and abrasion resistance of recycled roof tile aggregate were determined and compared to normal crushed stone aggregate.

Demolished roof tile (shown in Figure 1) made up of clay or cement, which was then crushed (shown in Figure 2) and sieved into coarse and fine recycled roof tile aggregate (shown in Figures 3 and 4 ) by the supplier. The recycled roof tile aggregate sample used in this study contains clay roof tile $(50 \%)$, cement roof tile (43\%) and others $(7 \%)$. For the preliminary investigation, the physical and mechanical properties of both fine and coarse recycled roof tile aggregate were determined, which provides opportunity to identify the main differences between recycled roof tile aggregate and normal crushed stone aggregate.

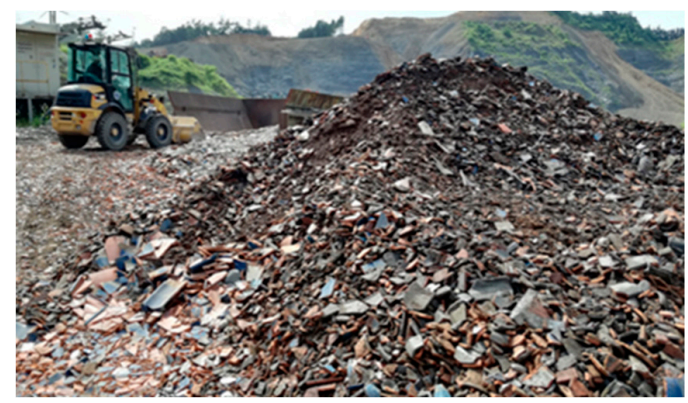

Figure 1. Waste roof tile before crushing.

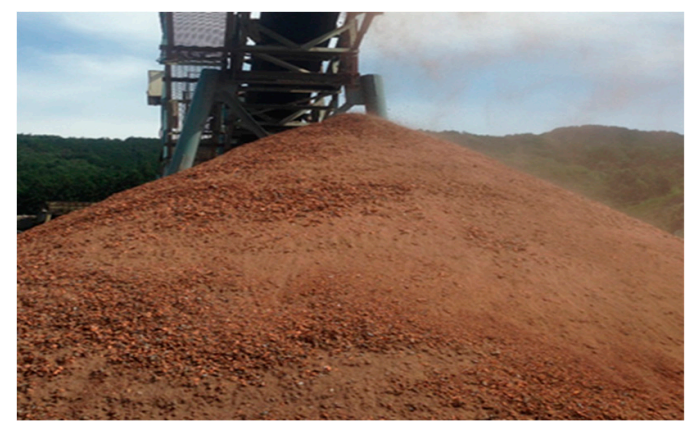

Figure 2. Crushed roof tile before sieving. 


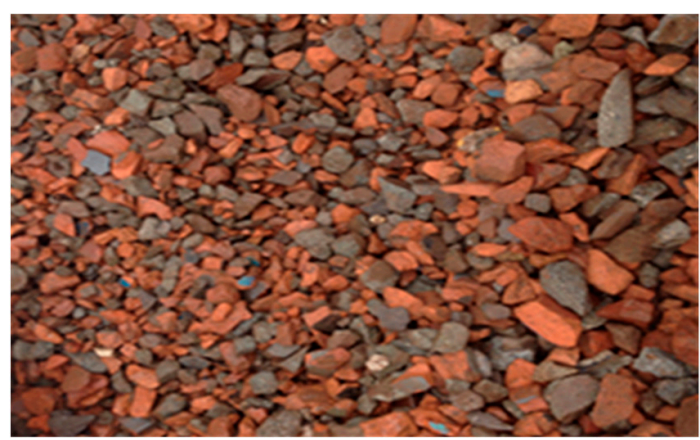

Figure 3. Coarse recycled roof tile aggregate.

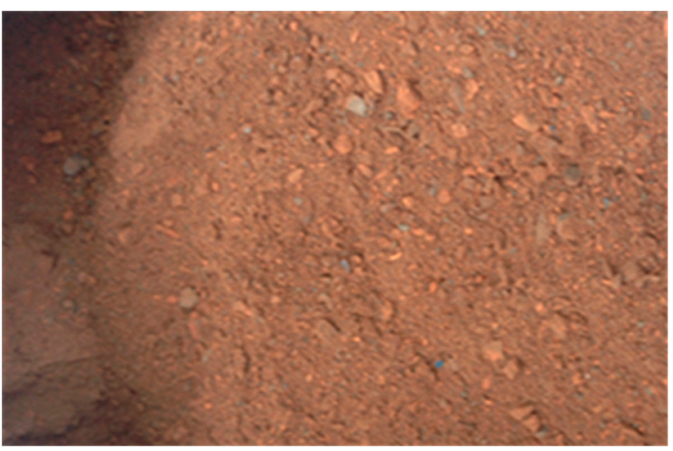

Figure 4. Fine recycled roof tile aggregate.

\subsection{Mix Proportion of Concrete}

Following a successful trial mixing, three mix proportions $G+S, R T G+S$, and RTS $+G$ were designed. During the first set, water-cement ratio $(w / c)$ was kept constant $(50 \%)$ in order to determine the properties of concretes RTG+S and G+RTS while in the second set it was varied to 30, 45 and $55 \%$ for the determination of strength and durability of RTG $+S$ concrete. Concrete G+S serves as control mix since it is composed of only normal aggregates. Concrete containing fine recycled roof tile aggregate (G+RTS) and coarse recycled roof tile aggregate concrete (RTG+S) were used to evaluate the effect of recycled roof tile aggregate on the strength and durability of concrete. Table 1 shows mixed proportions of concrete with different materials. AEWR was used in concrete with $w / c$ of $45 \%$, $50 \%$, and $55 \%$, while SP was used in concrete with $w / c$ of $30 \%$ to obtain desirable workability at low water cement ratio. Moreover, the sand-coarse aggregate ratio $(\mathrm{s} / \mathrm{a})$, which is the ratio of fine to coarse aggregate by volume, was varied for different concrete mixes, as shown in Table 1 . Specifically, the value of $s / a$ was taken to be smaller for the concrete mixture with lower water cement $(w / c=30 \%)$ and the concrete mixture containing fine aggregate with a lot of finer particles $(\mathrm{G}+\mathrm{RTS})$ in order to obtain better workability for casting and compaction.

Table 1. Material mix proportions of concrete.

\begin{tabular}{|c|c|c|c|c|c|c|c|c|c|c|c|}
\hline \multirow[b]{2}{*}{ Mix } & \multirow{2}{*}{$\begin{array}{l}w / c \\
(\%)\end{array}$} & \multirow{2}{*}{$\begin{array}{l}s / a \\
(\%)\end{array}$} & \multirow{2}{*}{$\begin{array}{c}\text { Air } \\
\text { Content } \\
(\%)\end{array}$} & \multirow{2}{*}{$\begin{array}{c}\text { Slump } \\
\text { (Slump } \\
\text { Flow) }(\mathrm{cm})\end{array}$} & \multicolumn{4}{|c|}{ Unit Content $\left(\mathrm{kg} / \mathrm{m}^{3}\right)$} & \multicolumn{3}{|c|}{ Unit Content $\left(\mathrm{mL} / \mathrm{m}^{3}\right)$} \\
\hline & & & & & W & C & $S$ & G & SP & AEWR & $\mathrm{AE}$ \\
\hline $\mathrm{G}+\mathrm{S}$ & \multirow{3}{*}{50} & 47 & 5.7 & 16.0 & 175 & 350 & 815 & 936 & - & 3500 & 3.5 \\
\hline G+RTS & & 36 & 5.5 & 12.0 & 190 & 380 & 522 & 1086 & - & 3800 & 38.0 \\
\hline RTG+S & & 47 & 6.5 & 20.0 & 180 & 360 & 805 & 795 & - & 3600 & 3.6 \\
\hline \multirow{3}{*}{ RTG+S } & 30 & 43 & 1.1 & $(71.0 \times 68.0)$ & 170 & 567 & 675 & 784 & 8400 & - & 3.8 \\
\hline & 45 & 46 & 5.4 & 21.0 & 180 & 400 & 773 & 794 & - & 4000 & 1.6 \\
\hline & 55 & 48 & 5.4 & 20.0 & 180 & 327 & 835 & 793 & - & 3600 & 3.6 \\
\hline
\end{tabular}

$w / c$ : water cement ratio; s/a: sand aggregate ratio; SP: superplasticizer. 


\subsection{Test Methods}

Preliminary investigation of aggregate properties like the gradation, density, water absorption, and strength was conducted on aggregates and the results are shown in Section 3.1. Trial mixes were used to approximate mix designs for the desired concrete fresh properties. Actual mix proportions that meet desired properties were cast.

For compressive strength test, modulus of elasticity and splitting tensile strength, cylindrical specimens of diameter $100 \mathrm{~mm}$ and depth $200 \mathrm{~mm}$ were prepared, cured at $20^{\circ} \mathrm{C}$ and test measurements done at 7, 28 and 91 days. For drying shrinkage, beam specimens $(100 \times 100 \times 400 \mathrm{~mm})$ were cast, cured at $20^{\circ} \mathrm{C}$ and kept in the temperature controlled room at $20^{\circ} \mathrm{C}$ and $60 \%$ Relative Humidity (R.H). Two specimens per mix proportion were used for the measurement of length change for a period of six months with measurements taken at ages $0,3,7,14,28,56,91$ and 182 days.

For chloride penetration test, sodium chloride $(\mathrm{NaCl})$ solution with a concentration of $10 \%$ was prepared and used in accordance with Japan Society of Civil Engineer (JSCE)-G 572-2007 [12]. Cylindrical specimens $(\varnothing 100 \times 200 \mathrm{~mm})$ were cured in water for 28 days and then dried for 7 days in a temperature controlled room. During the first day of drying, the specimen length was reduced by cutting off approximately $25 \mathrm{~mm}$ from both end faces. Epoxy coating was then applied on the specimens with the end faces exposed. Specimens were then immersed in sodium chloride $(\mathrm{NaCl})$ solution. After 91 and 182 days under $\mathrm{NaCl}$ solution, specimens were split and surfaces sprayed with solutions of silver nitrite and Uranine with $1 \%$ concentration. The penetration depth was then measured at 10 points on each end face of every split side and the average was taken as the penetration depth. For acid attack test and sulfate attack test, Japan Standard Test on Materials (JSTM) Building C 7401 [13] was used. Specimens $(100 \times 100 \times 400 \mathrm{~mm})$ were immersed in $2 \%$ hydrochloric acid $(\mathrm{HCl})$ solution and $10 \%$ Sodium sulfate $\left(\mathrm{Na}_{2} \mathrm{SO}_{4}\right)$ solution for acid attack and sulfate attack, respectively, for a period of 182 days. Change in weight and dynamic modulus of elasticity of specimens was used to evaluate the resistance of concrete. Freezing and thawing test was done in accordance with JIS A 1148:2010 [14]. The specimens $(100 \times 100 \times 400 \mathrm{~mm})$ were cured underwater for 28 days, and thereafter transferred to the freezing and thawing chamber for actual test. Freezing and thawing test was performed for 300 cycles with each cycle changing from $5{ }^{\circ} \mathrm{C}$ to $-18{ }^{\circ} \mathrm{C}$. Change in weight and dynamic modulus of elasticity of specimens was used to evaluate the frost resistance of concrete. For carbonation test, water cured specimens $(100 \times 100 \times 400 \mathrm{~mm})$ were kept in a temperature controlled room for 4 weeks. Between seven and eight weeks of age, the opposite top \& bottom surfaces along the $400 \mathrm{~mm}$ length, and both end surfaces were coated with epoxy resin. The test was conducted under recommended conditions for accelerating neutralization $\left(20 \pm 2{ }^{\circ} \mathrm{C}, 60 \pm 5 \%\right.$ R.H and carbon dioxide concentration $5 \pm 0.2 \%$ ). Specimens were put in the chamber with the uncoated side surfaces in a vertical direction and spacing of $20 \mathrm{~mm}$ between the specimens. At about a fifth of the specimen, it was split across, cleaned with a fine brush and phenolphthalein sprayed on the specimen cross-section. Phenolphthalein solution is made up of phenolphthalein powder, ethanol and water. Penetration depth at five points was measured when the promotion period reached 1, 4, 8, 13, and 26 weeks after the start of the accelerated test.

\section{Results}

\subsection{Properties of Aggregate}

Aggregate properties together with the water/cementitious ratio have a direct influence on fresh and hardened concrete properties as they govern the strength, workability, and durability. Recycled roof tile aggregate has higher water absorption, crushing values and abrasion values than the normal aggregate but exhibits lower specific gravity and bulk density, as shown in Table 2. Aggregates with such characteristic are generally referred to as low-quality aggregates due to the inferiority of such properties to normal concrete aggregate. Particle size distribution of aggregate is indeed an important parameter in determining paste requirement for workable concrete. Figures 5 and 6 shows the grading 
of aggregate used in the experiments with upper and lower limits specified by Japan Society of Civil Engineers. Grading of fine aggregate illustrates that fine recycled roof tile aggregate contains more than $20 \%$ of particles finer than $0.15 \mathrm{~mm}$ as shown by the gradation curve. Gradation curve of the coarse recycled roof tile aggregate shows better distribution.

Table 2. Physical and mechanical properties of aggregates and standards for test methods.

\begin{tabular}{cccccccc}
\hline $\begin{array}{c}\text { Aggregate } \\
\text { Type }\end{array}$ & Sample & $\begin{array}{c}\text { Specific } \\
\text { Gravity } \\
\text { (g/cm3) }\end{array}$ & $\begin{array}{c}\text { Water } \\
\text { Absorption } \\
\mathbf{( \% )}\end{array}$ & $\begin{array}{c}\text { Bulk } \\
\text { Density } \\
\mathbf{( k g / m 3 )}\end{array}$ & $\begin{array}{c}\text { Fineness } \\
\text { Modulus }\end{array}$ & $\begin{array}{c}\text { Abrasion } \\
\text { Value (\%) }\end{array}$ & $\begin{array}{c}\text { Crushing } \\
\text { Value (\%) }\end{array}$ \\
\hline $\begin{array}{c}\text { Fine } \\
\text { aggregate }\end{array}$ & River sand (S) & 2.59 & 2.55 & 1735 & 2.82 & N/A & N/A \\
\cline { 2 - 8 } & Roof tile (RTS) & 2.29 & 9.85 & 1340 & 2.55 & N/A & N/A \\
\hline $\begin{array}{c}\text { Coarse } \\
\text { aggregate }\end{array}$ & $\begin{array}{c}\text { Crushed stone } \\
(\mathrm{G})\end{array}$ & 2.64 & 0.76 & 1615 & - & 11.1 & 9.7 \\
\cline { 2 - 8 } & $\begin{array}{c}\text { Roof tile } \\
\text { (RTG) }\end{array}$ & 2.25 & 9.94 & 1300 & - & 33.5 & 28.4 \\
\hline \multicolumn{2}{c}{ Test methods } & JIS A 1110 [15] & $\begin{array}{c}\text { JIS A 1104 } \\
{[16]}\end{array}$ & $\begin{array}{c}\text { JIS A 1102 } \\
{[11]}\end{array}$ & $\begin{array}{c}\text { JIS A 1121 } \\
{[17]}\end{array}$ & BS 812 [18] \\
\hline
\end{tabular}

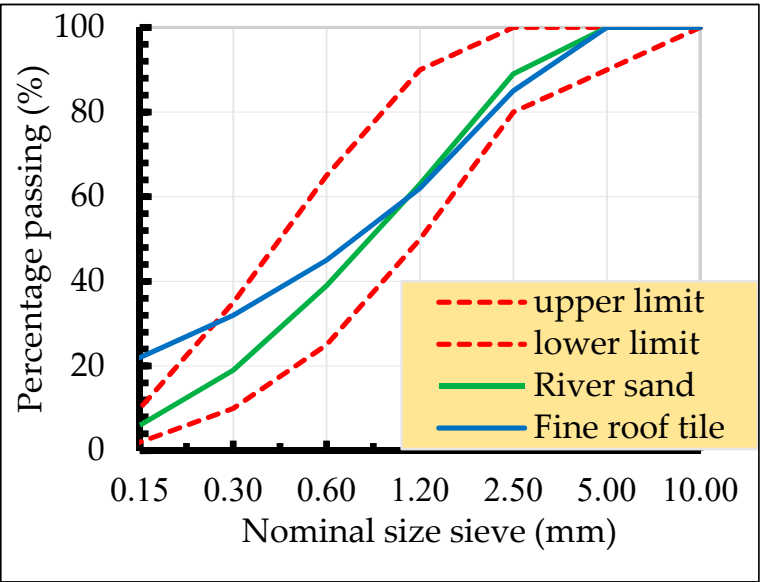

Figure 5. Grading of fine aggregate.

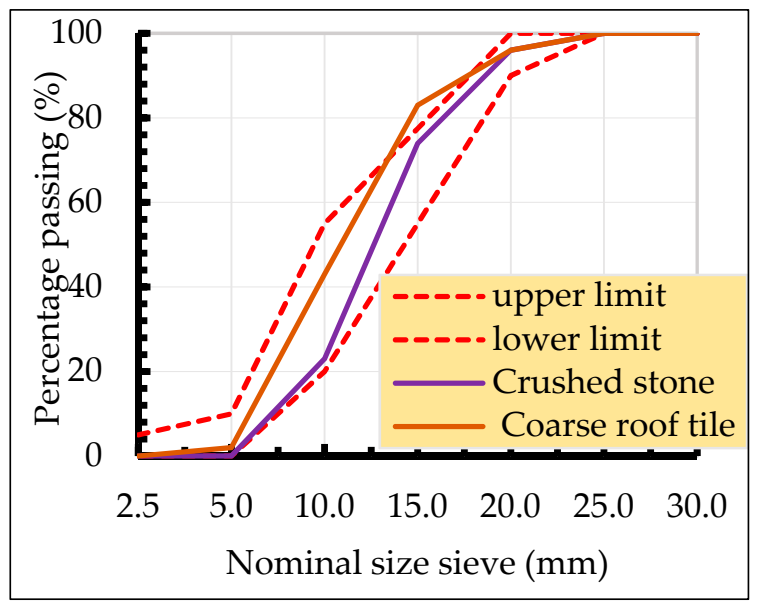

Figure 6. Grading of coarse aggregate.

\subsection{Fresh Properties}

The standard test for fresh properties of concrete was carried out to verify workability, which was recorded immediately after every mix as per universal recommendation. Slump value, air content and temperature of both normal aggregate concrete and recycled roof tile aggregate concrete were 
recorded. Although both recycled roof tile and normal aggregates were used in a surface saturated dry condition, the workability of concrete containing fine recycled roof tile (G+RTS) showed lower slump value, while concrete with coarse recycled roof tile $(\mathrm{RTG}+\mathrm{S})$ has higher slump value than the control mix. The slump value of G+RTS concrete has decreased by about $27 \%$, while RTG+S concrete increased by $14 \%$ with respect to the control mix. Interestingly, G+RTS concrete decreased in slump despite $12 \%$ higher in water content, while RTG $+\mathrm{S}$ concrete used $6 \%$ higher water content as compared to G+S concrete. For RTG $+\mathrm{S}$ concrete with a $w / c$ ratio of $30 \%$, slump flow $(71.0 \mathrm{X} 68.0 \mathrm{~mm})$ was measured due to high workability, which is the diameter of concrete after subsidence.

As per setting time, the results show longest elapsed time from initial to final setting of concrete containing fine recycled roof tile, as shown in Figure 7. Apparently, there is little difference in initial setting time but a marginal difference in the final setting time, especially between the control mix and RTG+S. Nonetheless, a big margin was observed in the final setting time, especially between the control mix and G+RTS concrete.

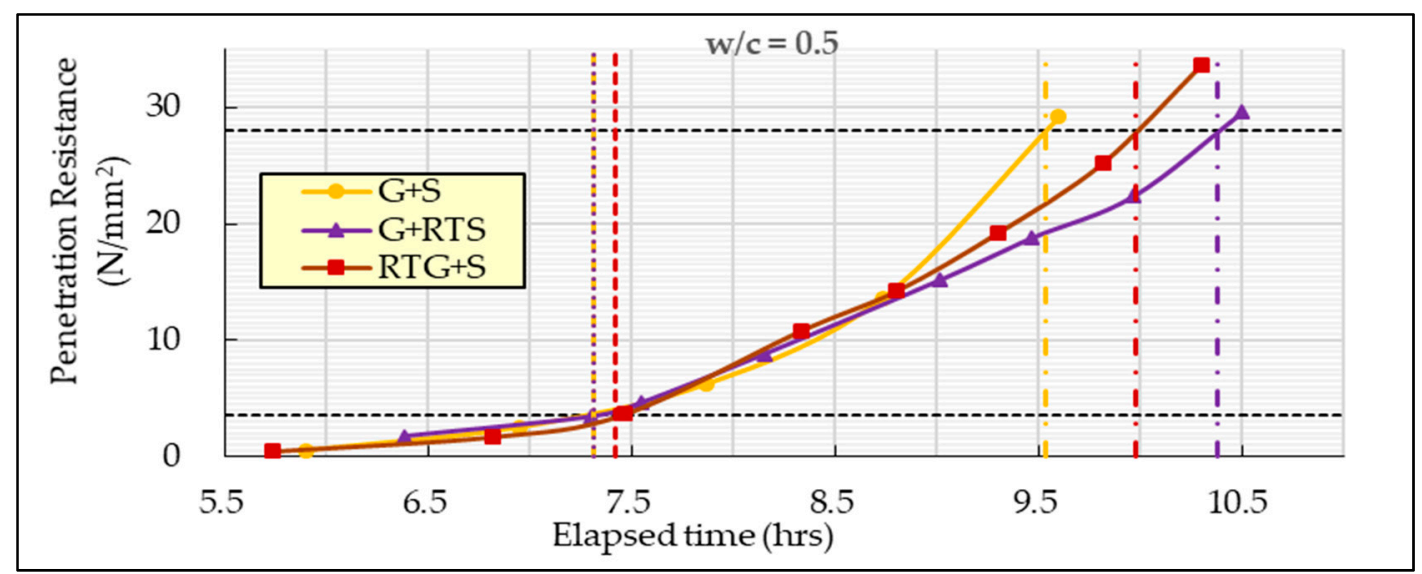

Figure 7. Effect of aggregate on initial and final setting time of concretes.

\subsection{Hardened Properties of Concrete}

\subsubsection{Mechanical Properties}

Figure 8 shows the relationship between compressive strength of concrete samples with cement-water ration $(c / w)$ whereas Figure 9 shows strength development of the different concretes with age. Fitting lines and their corresponding equations at $7 \& 28$ days compressive strength are generated for the determination of water cement ratio $(w / c)$ of RTG $+S$ concrete and control mix at the same compressive strength. According to generated equations for 28 days compressive strength, for $40 \mathrm{~N} / \mathrm{mm}^{2}$ and $80 \mathrm{~N} / \mathrm{mm}^{2}, w / c$ of RTG $+\mathrm{S}$ concrete decreased by $4 \%$ and $9 \%$, respectively, compared to normal concrete. This implies that cement content would increase if recycled roof tile aggregate is used for high strength concrete as compared to normal aggregate concrete. As for normal strength concrete, difference in $w / c$ is small and this meant that the disadvantage is minor.

Figure 10 shows the splitting tensile strength of concrete containing coarse recycled roof tile aggregate with $w / c 30,45 \& 50 \%$. The relationship between compressive and tensile strength of concrete with coarse recycled roof tile aggregate and normal aggregate concrete is shown in Figure 11. Predicted values obtained from Equation (1), which is suggested by "Guidelines for Control of Cracking of Mass Concrete" [19] published by Japan Concrete Institute (JCI), are also shown in Figure 11. Observed results are similar to tensile strength calculated from JCI prediction values and as a result, the JCI model equation can be applied to predict tensile strength of $\mathrm{RTG}+\mathrm{S}$ concrete. Results for modulus of elasticity of the three types of concrete are shown in Figure 12, while Figure 13 shows the relationship between compressive strength and modulus of elasticity of concretes $G+S$ and RTG $+S$. Predicted values for modulus of elasticity based on compressive strength were obtained using Equation (2), proposed by JCI Guidelines [19]. Modulus of elasticity of RTG+S concrete is lower than the predicted values by JCI 
model. This implies that JCI model equation is not appropriate to be used in predicting modulus of elasticity for RTG $+\mathrm{S}$ concrete. Therefore, $60 \%$ of the values predicted by Equation (2) for modulus of elasticity for RTG $+\mathrm{S}$ concrete were used.

$$
\begin{aligned}
\mathrm{f}_{\mathrm{t}}(\mathrm{t}) & =0.13 \times \mathrm{f}_{\mathrm{c}}{ }^{\prime}(\mathrm{t})^{0.85} \\
\mathrm{E}_{\mathrm{C}}(\mathrm{t}) & =6300 \times \mathrm{f}_{\mathrm{C}}{ }^{\prime}(\mathrm{t})^{0.45}
\end{aligned}
$$

Where,

Ec $(t)$ : Modulus of elasticity of concrete at age $t\left(N / \mathrm{mm}^{2}\right)$;

$\mathrm{ft}(\mathrm{t})$ : Splitting tensile strength of concrete at age $\mathrm{t}\left(\mathrm{N} / \mathrm{mm}^{2}\right)$;

$\mathrm{fc}^{\prime}(\mathrm{t})$ : Compressive strength of concrete at age $\mathrm{t}\left(\mathrm{N} / \mathrm{mm}^{2}\right)$;

$\mathrm{t}$ : age of concrete (days).

Figure 14 illustrates that G+RTS concrete showed fastest and highest shrinkage, whereas RTG+S concrete demonstrated the slowest shrinkage during first two months. Maximum shrinkage for mix containing fine recycled roof tile exceeded the limit value of $800 \times 10^{-6}$ micro-strain during the six month period.

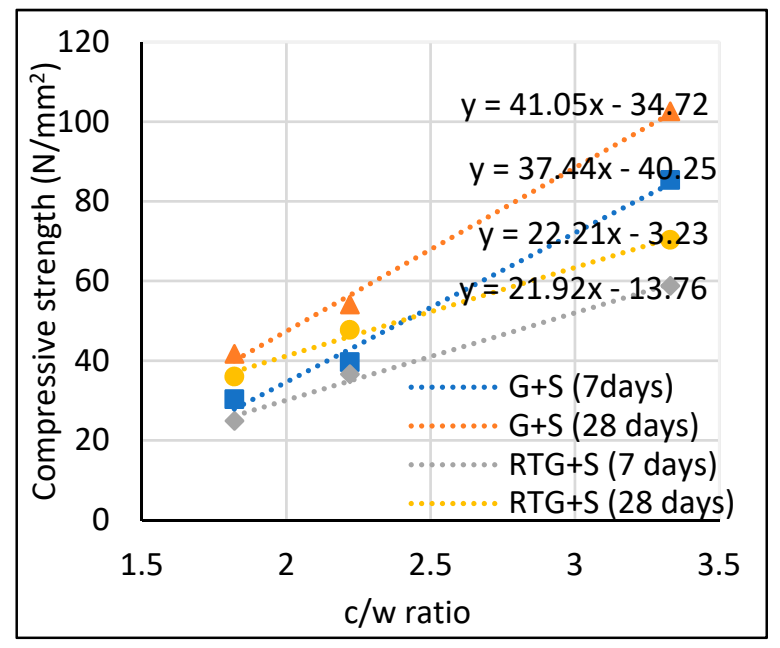

Figure 8. Relationship between compressive strength \& $c / w$ of concrete samples.

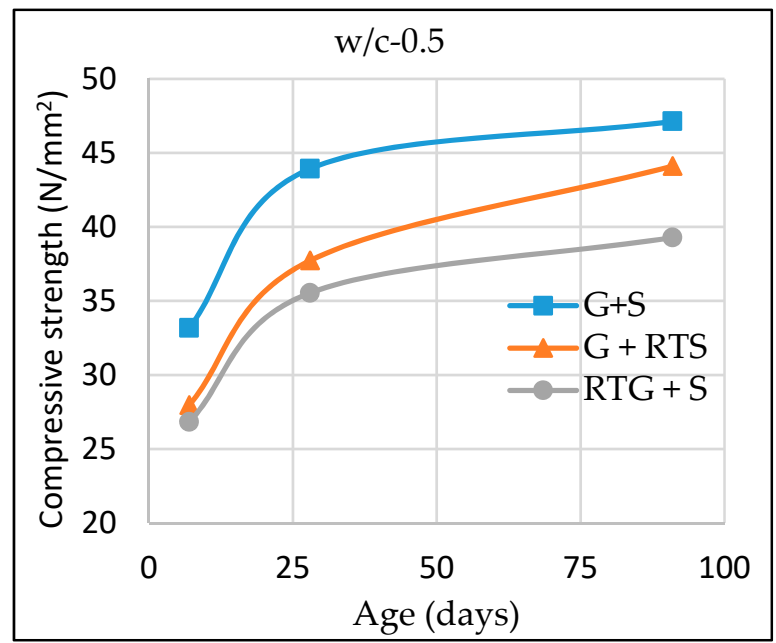

Figure 9. Compressive strength of concretes. 


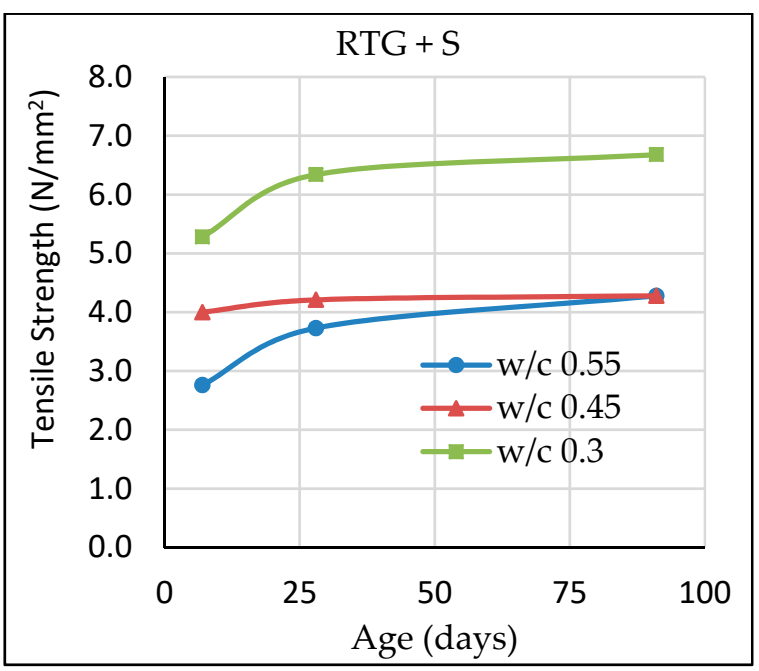

Figure 10. Compressive strength of concretes.

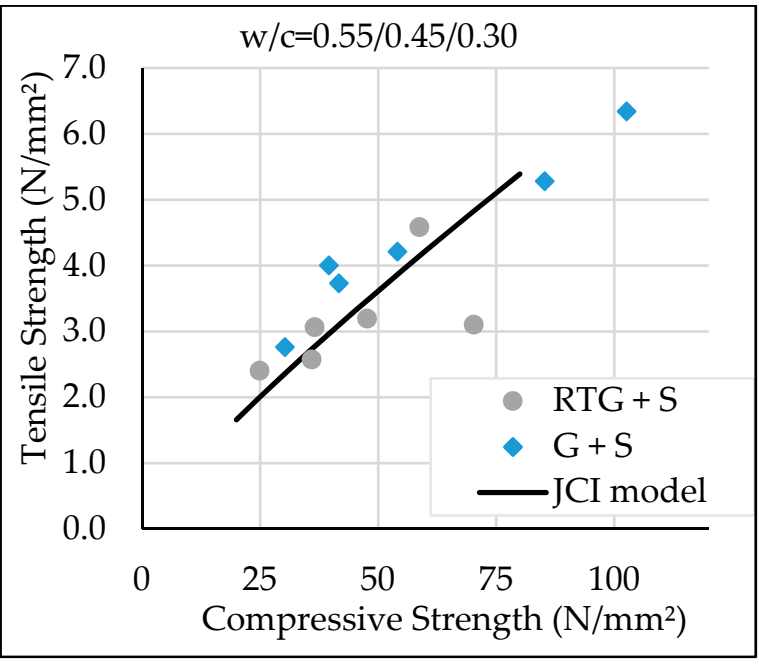

Figure 11. Compressive/Tensile strength of concretes.

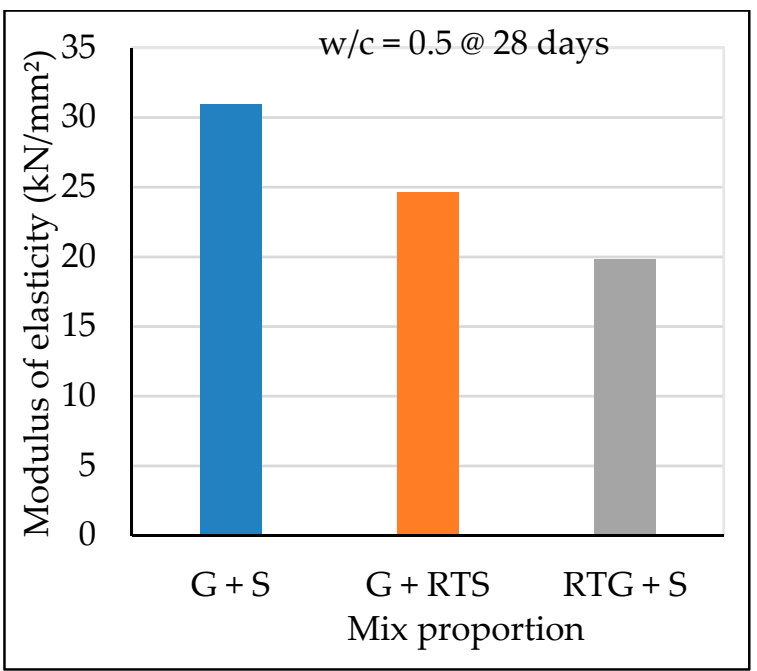

Figure 12. Modulus of elasticity of concretes. 


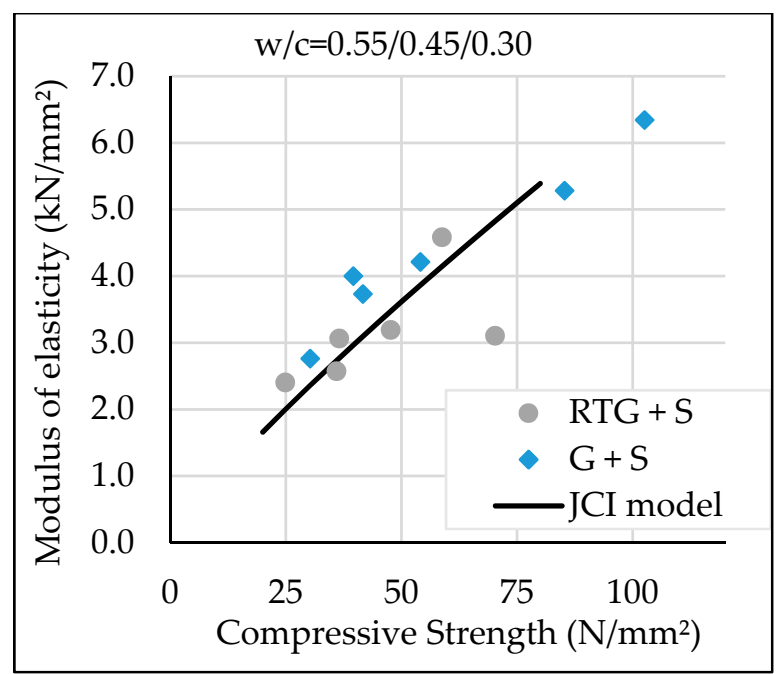

Figure 13. Elasticity/compressive strength relationship.

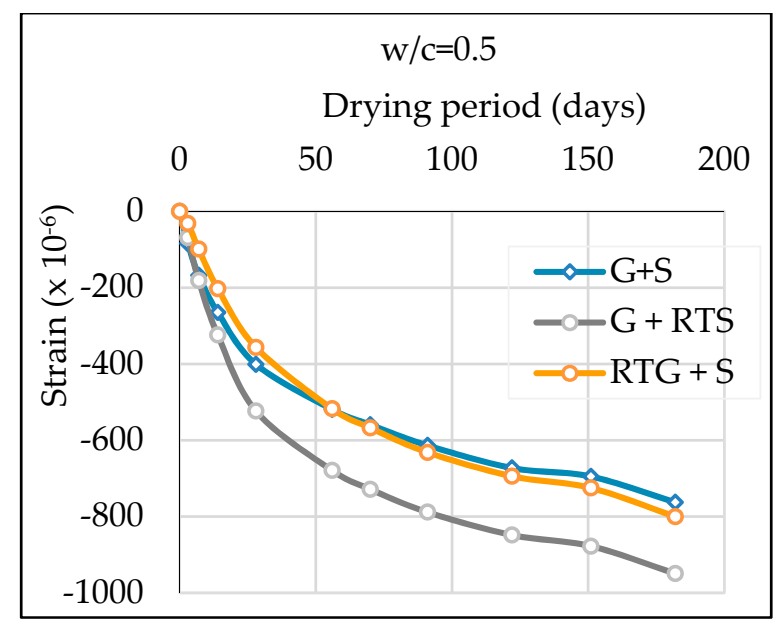

Figure 14. Drying shrinkage of concretes.

\subsubsection{Durability}

Test results for carbonation of RTG $+\mathrm{S}$ concrete were almost similar to $\mathrm{G}+\mathrm{S}$ concrete, as shown in Figure 15. In view of the foregoing, chloride penetration depths for RTG $+S$ and $G+S$ concretes were also similar, as illustrated in Figure 16. Since the penetration depth is highly dependent on porosity of concrete matrix, obtained results for both carbonation and chloride penetration might seem different from expected results due to high absorption rate of recycled roof tile aggregate. Study shows poor performance of RTG $+S$ concrete against freezing and thawing, with drastic change in the dynamic modulus of elasticity and subsequent failure after 150 cycles. It can be observed that the relative dynamic modulus of elasticity of RTG $+S$ concrete significantly decreased after only 30 cycles. The values at 30 and more cycles are in the range of $20 \%$ and $40 \%$, and they are much lower than $60 \%$, which is regarded as the general target for concrete with freezing and thawing durability. The fluctuation in the observed data can be seen in RTG $+S$ concrete, as shown in Figure 17. This is because the precise measurements of dynamic modulus of elasticity are often difficult on concrete specimens severely damaged by freezing and thawing cycles. Figure 18 shows changes in the dynamic modulus of elasticity of concretes RTG $+\mathrm{S}$ and $\mathrm{G}+\mathrm{S}$ exposed to both $\mathrm{HCl}$ and $\mathrm{Na}_{2} \mathrm{SO}_{4}$. Similarly, Figure 19 shows change in mass of concrete exposed to both $\mathrm{HCl}$ and $\mathrm{Na}_{2} \mathrm{SO}_{4}$ solutions. Results showed greater loss in both dynamic modulus of elasticity and mass of concrete when exposed to hydrochloric acid than a sodium sulfate solution with fast drop experienced during the first month. 
Overall, obtained results depict minor effect of coarse recycled roof tile aggregate against hydrochloric acid attack and sodium sulfate attack, since the change in the dynamic modulus of elasticity and mass for both $\mathrm{G}+\mathrm{S}$ concrete and $\mathrm{RTG}+\mathrm{S}$ concrete are similar throughout.

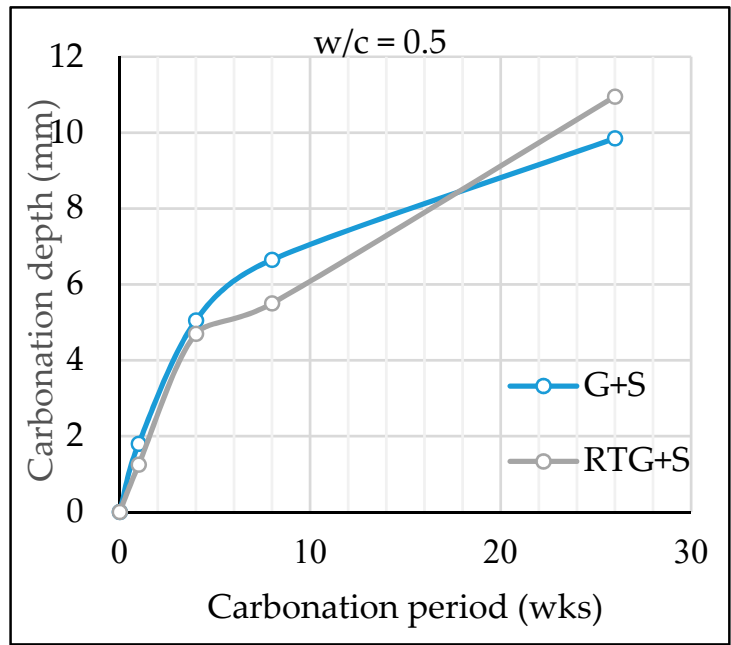

Figure 15. Carbonation depth of concretes.

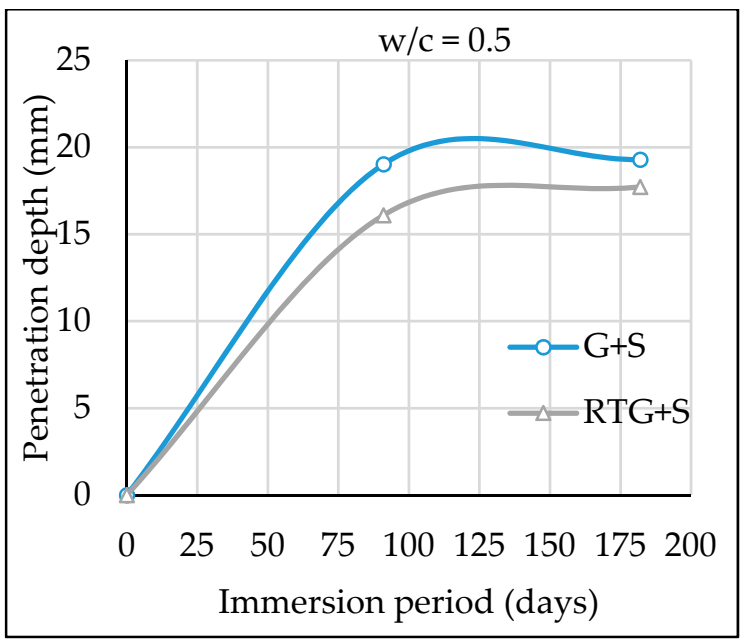

Figure 16. Chloride penetration depth ( $10 \% \mathrm{NaCl}$ solution).

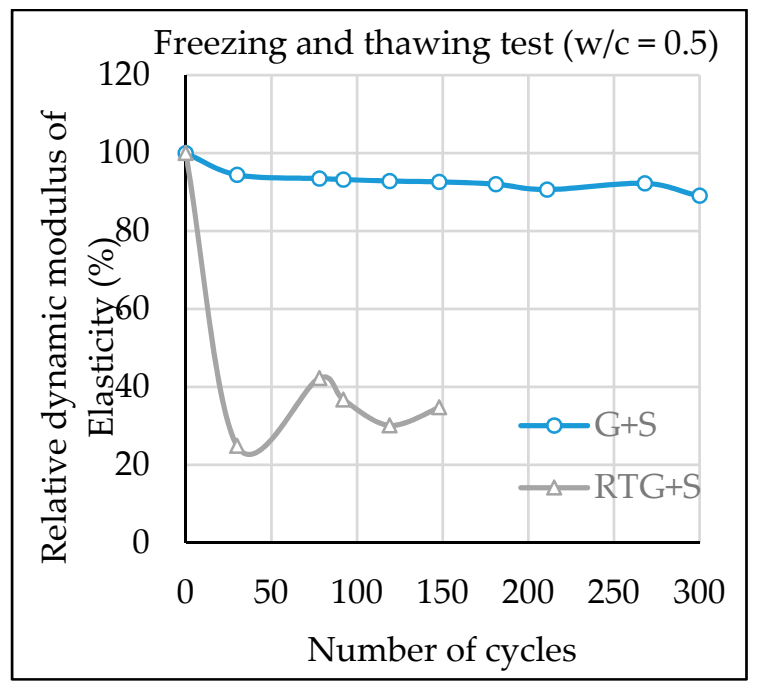

Figure 17. Dynamic modulus of elasticity of concretes. 


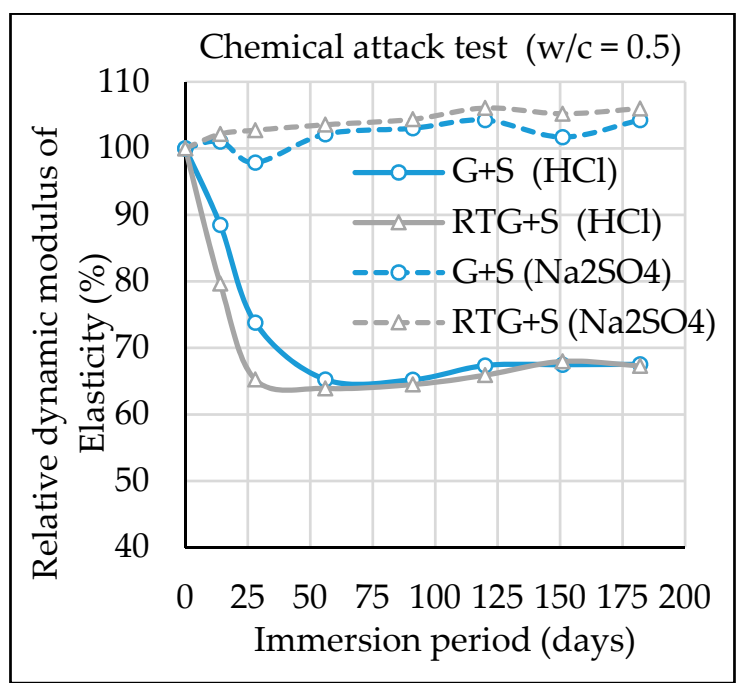

Figure 18. Dynamic modulus of elasticity of concretes.

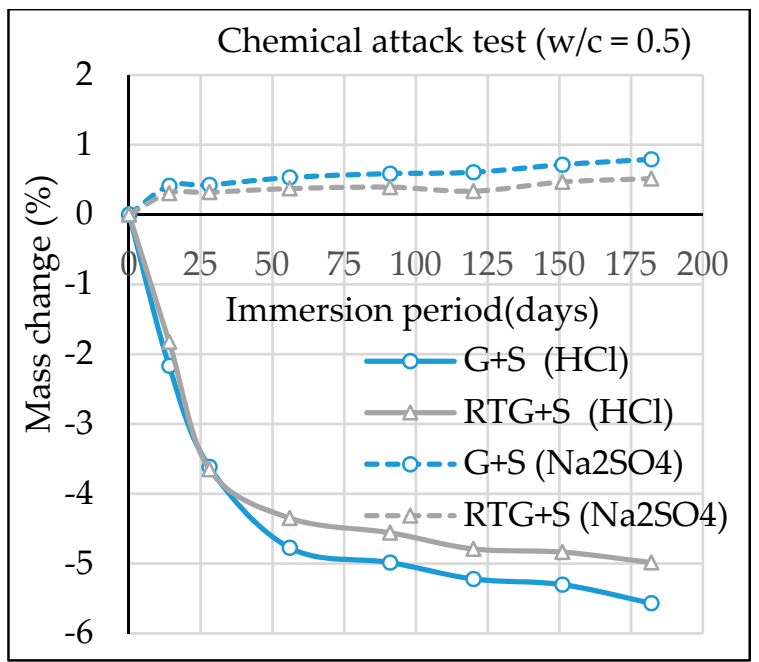

Figure 19. Rate of weight change of concrete.

\section{Discussions}

Physical and mechanical properties of aggregates play an important role in the overall strength and performance of concrete, both in the fresh and hardened state. Experimental results indicate that recycled roof tile aggregate had a higher porosity, water absorption and contaminant content, lower density, lower crushing value, and lower abrasion resistance than natural aggregate. Such data justify that the recycled roof tile aggregate used in this study was inferior to normal crushed stone aggregate and as a result yielded concrete with lower density.

G+RTS concrete used relatively higher water content and higher dosage of AE. This is because RTS includes a very large amount of fine particles, which absorb AE agent on their surfaces [20]. Compressive strength of concrete at ages 7,28 and 91 days were measured for evaluation of strength development during the first three months after casting. Observed compressive strength of recycled roof tile aggregate concrete was lower than normal aggregate concrete, especially at low water cement ratio. It was reported by Midorikawa et. al. [21] that compressive strength with $w / c$ of 0.5 containing clay roof tile coarse aggregate (absorption: 9.6\%) was higher than normal aggregate concrete and that this was due to good bonding between cement paste and aggregate particles with rough surfaces. However, similar trend could not be found in this study. This may be because the samples of recycled roof tile aggregate used in this study were different in properties of strength and texture. Moreover, 
experimental results showed that concrete containing coarse recycled roof tile aggregate $(\mathrm{RTG}+\mathrm{S})$ had low strength as compared to concrete with fine recycled roof tile aggregate (G+RTS). These results indicate that coarse recycled roof tile aggregate had a larger influence on strength of concrete when $100 \%$ of coarse or fine aggregate was replaced by recycled roof tile aggregate.

Test data indicate lower modulus of elasticity of concrete containing recycled roof tile aggregate than the normal aggregate concrete mix. Studies by Bui et al. [6] indicates that the partial replacement of normal coarse aggregate by recycled roof tile aggregate at a $40 \%$ replacement ratio by volume decreases modulus of elasticity of concrete by $4.9-12.8 \%$. This trend was also reported in a published paper by Tobita et al. [7], which demonstrated that modulus of elasticity of clay roof tile aggregate concrete was significantly lower than that of normal aggregate concrete. Predicted relationships with compressive strength of modulus of elasticity $E_{c}(t)$ and splitting tensile strength $\mathrm{f}_{\mathrm{c}}{ }^{\prime}(\mathrm{t})$ were obtained using the JCI 2016 guidelines, as previously described in Section 3.3.1. The graphs show that JCI model Equation (1) can be used to predict the splitting tensile strength of concrete RTG $+S$ but Equation (2) is not suitable for prediction of modulus of elasticity of the same concrete type. As a result, the authors have proposed use of " 0.6 " of JCI model equation to predict modulus of elasticity for concrete containing coarse recycled roof tile. This reduction coefficient, " 0.6 " is about the same as that for modulus of elasticity of light-weight aggregate concrete proposed by Japanese specification for structural design of concrete structures [22].

The permeability of concrete is associated with the pore structure of paste matrix and aggregate, which means that the rate of ingress of substances such as sodium, chloride, carbon dioxide, etc., into concrete is highly dependent on the pore structure of the concrete. Concrete $\mathrm{RTG}+\mathrm{S}$ showed similar or better performance against chloride ingress and carbonation as compared to $\mathrm{G}+\mathrm{S}$ concrete, which implies that such concrete could be a good option in carbonated or chloride aggressive environments such as coastal and marine structures. These experimental results showed that high porosity of recycled roof tile aggregate does not cause high rates of ingress of substances. It was reported in published papers that the use of roof tile aggregate improved resistance to carbonation and chloride ion penetration of concrete. It was also reported by Muragishi et al. [23] that the moisture in roof tile aggregate particles might have the effect of internal curing, which densify the microstructure of cement hydration. It can be seen that the experimental results of carbonation and chloride ion penetration shown in this study also support the idea of internal curing by roof tile aggregate.

By visual observation of samples during the study, deterioration of specimens was more when exposured to the hydrochloric acid $(\mathrm{HCl})$ solution than sodium sulfate $\left(\mathrm{Na}_{2} \mathrm{SO}_{4}\right)$ solution. Research has it that by visual verification of samples after 6 months, deterioration of the specimen was more when exposured to the acidic solution than sulfate solution [24]. For freezing and thawing resistance, test results of dynamic modulus of elasticity showed a drastic change for concrete RTG+S and subsequent failure just after 150 cycles. The overall data indicate that recycled roof tile aggregate concrete has poor durability against freezing and thawing. These findings agree with experimental results in a published paper by Kasai et al. [25], in which pour frost resistance was observed in concrete with clay roof tile coarse aggregate with absorption of $7.86 \%$. Henceforth, it is suggested that recycled roof tile aggregate is not suitable for concrete structures in severe freeze-thaw exposure conditions. Overall, the obtained data showed the interesting durability performance of recycled roof tile aggregate in concrete, but the additional study will be helpful to counter check the findings of this study.

\section{Conclusions}

The results obtained allow the following conclusions to be drawn:

- Results of water absorption, specific gravity, crushing value and abrasion value show that recycled roof tile has inferior physical properties than normal crushed stone aggregate.

- The compressive strength, splitting tensile strength, drying shrinkage and modulus of elasticity of concrete containing recycled roof tile aggregate becomes a concern when it is used for high strength. 
- The JCI model equation is not recommended for prediction of modulus of elasticity for concrete containing recycled roof tile aggregate. A modified equation of the JCI can be used to predict modulus of elasticity for concrete containing recycled roof tile and this equation was used in this study.

- Test data shows poor performance of concrete containing recycled roof tile against freezing and thawing as compared to normal aggregate concrete. No adverse effect of recycled roof tile aggregate against carbonation, acid attack, and chloride penetration.

Author Contributions: Both authors have actively participated in the conceptualization and investigation of the work, analysis and interpretation of data and documentation of this study. The first author prepared the original draft of this article under the guidance and supervision of the second author.

Funding: This research received no external funding except the support of the Japan International Cooperation Agency (JICA) through the Africa Business Education (ABE) initiative scholarship awarded to the first author.

Acknowledgments: The authors are indeed grateful to the management and staff of the Civil and Environmental Engineering Department of Ashikaga University for their unflinching support during this study.

Conflicts of Interest: The authors hereby declare no conflicts of interest as far as the publication of this journal is concerned.

\section{References}

1. Etxeberria, M.; Vegas, I. Effect of Fine Ceramic recycled aggregate (RA) and mixed fine RA on hardened properties of concrete. Mag. Concr. Res. 2014, 67, 645-655. [CrossRef]

2. Shafii, F. Achieving Sustainable Construction. In Proceedings of the 6th Asia-Pacific Structural Engineering and Construction Conference (APSEC 2006), Kuala Lumpur, Malaysia, 5-6 September 2006.

3. Andrés, J.; César, M.; Guerra, M.I.; Julia, M.M.; Aguado, P.J.; Sánchez de Rojas, M.I.; Frías, M.; Rodríguez, O. Re-use of ceramic wastes in construction. Cera. Mater. 2010, 10, 197-214.

4. Giridhar, V.; Rao, H.S.; Kumar, P.S.P. Influence of ceramic waste aggregate properties on strength of ceramic waste aggregate concrete. IJRET 2015, 4, 15-24.

5. Kumar, R. Influence of recycled coarse aggregate derived from construction and demolition waste (CDW) on abrasion resistance of pavement concrete. Constr. Build. Mater. 2017, 142, 248-255. [CrossRef]

6. Bui, P.T.; Ogawa, Y.; Nakarai, K.; Sato, R. Internal curing of Class-F fly-ash concrete using high-volume roof-tile waste aggregate. Mater. Struc. 2017, 50, 4. [CrossRef]

7. Tobita, H.; Uehara, T.; Umehara, H.; Yutake, H. Study on applicability of disposed roof tile as aggregate for concrete. Proc. Jpn. Concr. Inst. 2006, 28, 1577-1582. (In Japanese)

8. Sugiyama, M. The Compressive Strength of Concrete Containing Tile Chips, Crushed Scallop Shells, or Crushed Roofing Tiles. In Proceedings of the International RILEM Conference on the Use of Recycled Materials in Buildings and Structures, Barcelona, Spain, 8 November 2004; pp. 658-664.

9. Japanese Standards Association. JIS R 5210: Portland Cement; Japanese Standards Association: Tokyo, Japan, 2009.

10. Japanese Standards Association. JIS A 6204: Chemical Admixtures for Concrete; Japanese Standards Association: Tokyo, Japan, 2011.

11. Japanese Standards Association. JIS A 1102: Method of Test for Sieve Analysis of Aggregates; Japanese Standards Association: Tokyo, Japan, 2014.

12. Japanese Society of Civil Engineers. JSCE G 572: Determination Method of Apparent Diffusion Coefficient of Chloride Ion in Concrete by Immersion; Japanese Society of Civil Engineers: Tokyo, Japan, 2003.

13. Japan Testing Center for Construction Materials. JSTM C 7401: Method of Test for Chemical Resistance of Concrete in Aggressive Solution; Japan Testing Center for Construction Materials: Tokyo, Japan, 1999.

14. Japanese Standards Association. JIS A 1148: Method of Test for Resistance of Concrete to Freezing and Thawing; Japanese Standards Association: Tokyo, Japan, 2010.

15. Japanese Standards Association. JIS A 1110: Methods of Test for Density and Water Absorption of Coarse Aggregates; Japanese Standards Association: Tokyo, Japan, 2006.

16. Japanese Standards Association. JIS A 1104: Methods of Test for Bulk Density of Aggregates and Solid Content in Aggregates; Japanese Standards Association: Tokyo, Japan, 2006. 
17. Japanese Industrial Standards Association. JIS A 1121: Test for Resistance to Abrasion of Coarse Aggregate by Use of the Los Angeles Machine; Japanese Industrial Standards Association: Tokyo, Japan, 2007.

18. British Standards Institution. BS 812.110: Methods of determination of aggregate crushing value (ACV). 1990. Available online: http://saliergeotechnical.co.uk/British\%20Standards\%20NEW/BS\%20EN\%20812/BS\% 20812-110\%201990.pdf (accessed on 29 June 1990).

19. Japan Concrete Institute. Guidelines for Control of Cracking of Mass Concrete; Japan Concrete Institute: Tokyo, Japan, 2016.

20. Neville, A.M. Properties of Concrete, 4th ed.; John Wiley \& Sons, Inc.: New York, NY, USA, 1996.

21. Midorikawa, T.; Nemoto, Y.; Ohno, H. Study on Utilization of Disposed Roof Tile as Material for Concrete. In Proceedings of the 64 the Annual Meeting of Japan Society of Civil Engineers, Fukuoka, Japan, 2 September 2009; pp. 717-718. (In Japanese).

22. Japan Society of Civil Engineers. Standard Specification for Concrete Structures- Design. 2007. Available online: http://www.jsce.or.jp/committee/concrete/e/Standard_specification/JGC15_Design_1.0.pdf (accessed on December 2010).

23. Muragishi, Y.; Ogawa, Y.; Kawai, K.; Sato, R. Effect of internal curing by disposed roof tile coarse aggregate in fly ash concrete subjected to steam curing. Proc. Jpn. Concr. Inst. 2014, 36, 670-675.

24. Hill, J.; Byars, E.A.; Sharp, J.H.; Lynsdale, C.J.; Cripps, J.C.; Zhou, Q. An experimental study of combined acid and sulfate attack of concrete. Cem. Concr. Compos. 2003, 25, 997-1003. [CrossRef]

25. Amano, Y.; Uehara, T.; Umehara, H.; Takenaga, Y. Utilization of Waste Sansyu Roof Tiles for Concrete. Concr. Resear. Tech. 2010, 2,1-11.

(C) 2019 by the authors. Licensee MDPI, Basel, Switzerland. This article is an open access article distributed under the terms and conditions of the Creative Commons Attribution (CC BY) license (http://creativecommons.org/licenses/by/4.0/). 